\title{
Evaluation of histological changes in peri-implant bone tissue after ultrasound application at early healing stages
}

\section{S.P. Rubnikovich ${ }^{\mathrm{a}}$, I.S. Khomich ${ }^{\mathrm{b}}$}

${ }^{\mathrm{a}} \mathrm{MD}, \mathrm{PhD}$, DMSci, Professor, Belarusian Medical Academy of Postgraduate Education, Minsk, Belarus ${ }^{\mathrm{b}} \mathrm{MD}, \mathrm{PhD}$, Belarusian Medical Academy of Postgraduate Education, Minsk, Belarus

\section{Received 22.08.18}

Accepted 24.08.18

Keywords: bone regeneration, osteoblasts, ultrasound, dental implants, histology

\begin{abstract}
The aim was to study the nature of the morphological changes over time in the bone tissue around the implants under the influence of low-intensity pulsed ultrasound in the experiment. Materials and methods. Experimental studies were carried out on rabbits of the chinchilla breed, with dental implants installed in the tibia - two experimental groups with ultrasound and one control group. The animals were withdrawn from the experiment at 1,2, 4 and 8 weeks and histological examination of the sections of periimplant tissues was carried out. Results. The processes of osseointegration of dental implants in all groups of animals occurred without disrupting the normal process sequence. In the early stages granulation tissue is formed, later it is replaced by fibrous-reticular and coarse-fibrous bone tissue, and at the end by a more mature lamellar bone tissue. However, the timing and degree of maturation of bone tissue, as well as osseointegration of implants in groups using low-frequency low-intensity pulsed ultrasound and without it differed significantly. The study showed that ultrasound exposure to implants and surrounding tissues induces osteoreparation processes, stimulating neoangiogenesis in granulation and newly formed bone tissue. Conclusion. Application of ultrasound to implants and subsequent application to the periimplant tissues during and after dental implantation promotes the formation of bone tissue, identical by the histostructure to the maternal bone.
\end{abstract}

\section{Оценка гистологических изменений в околоимплантной кости после УАьтразвукового возАействия в ранний периоА заживАения}

\section{С.П. Рубникович ${ }^{\mathrm{a}}$, И.С. Хомич \\ ${ }^{\mathrm{a}} \mathrm{A}$-р меА. наук, профессор, Белорусская медицинская академия последипломного образования, Минск, Беларусь \\ 'канд. меА. наук, Белорусская медицинская академия послеАипмомного образования, Минск, Беларусь}

УДК: $616.314-007.21: 616.314-$
77-089.843]-085.837.3

Поступима в редакцию 22.08.18

Принята к печати 24.08 .18

Кмючевые слова: восстановцение кости, остеобласты, умьтразвук, имплантаты гистология

\section{PЕЗЮМЕ}

В проведенном исслеАовании стояла цемь - изучить природу морфологических изменений в костной ткани вокруг имплантатов поА возАействием импульсного умьтразвука низкой интенсивности в эксперименте с течением времени. Материахы и методы. Экспериментальные исслеАования проводимись на кроликах породы шиншимла, в большеберцовую кость которым устанавливали Аентальные имплантаты - Аве экспериментальные группы с ультразвуковым воздействием и одна контрольная. Животных выводили из эксперимента через 1, 2, 4 и 8 недель и проводили гистологическое исследование срезов периимплантных тканей. Резумьтаты. Процессы остеоинтеграции дентальных имплантатов во всех группах животных происходили без нарушения последовательности этапов. На ранних стадиях формируется грануяяционная ткань, позАнее она заменяется фиброретикулярной и грубоволокнистой костной, а в конце - более зрелой пластинчатой костной тканью. ОАнако сроки и степень созревания костной ткани, а также остеоинтеграции имплантатов в группах с использованием низкочастотного импульсного ультразвука низкой интенсивности и без него существенно различались. ИсслеАование показало, что воздействие ультразвука на имплантаты и окружающие ткани индуцирует процессы остеорепарации, стимулируя неоангиогенез в грануляционной и новообразованной костной ткани. Закмючение. Озвучивание имплантатов и последующее ультразвуковое воздействие на периимплантные ткани при дентальной имплантации способствует формированию костной ткани, приближенной по гистоструктуре к материнской кости.
Correspondence to /

ААрес Аля корреспонденции:
E-mail:

rubnikovichs@mail.ru 
$\mathrm{D}$ ental implants can significantly improve the ability to restore chewing efficiency in patients with dentition defects, improve the fixation of removable dentures or replace them with non-removable dentures, and today dental implantation is a well-studied and widely used treatment method all over the world. However, there is a continuous search for opportunities to improve the surface properties and geometry of implants, surgical techniques and possible influences on the complex of tissues surrounding the implant to optimize the osseointegration processes and reduce the risks of peri-implantitis, which will prolong the functioning of implants. Since the beginning of the 1990s, studies of the potential therapeutic effects of ultrasound on the bones of the maxillofacial region were being performed, and most of these studies have reported positive results. Researchers have shown that the application of ultrasound increases the synthesis of angiogenesis-related cytokines such as interleukin 8 , fibroblast growth factor, and vascular endothelial growth factor. Studies have confirmed the ability of ultrasound therapy to improve healing of mandibular fractures and osteoradionecrosis, enhance the proliferation of fibroblasts and osteoblasts. With its unique ability to accelerate bone repair, low-intensity pulsed ultrasound may be a promising new method to improve the quality of osseointegration of dental implants [1-26].

\section{THE AIM OF THE RESEARCH}

To study the nature of morphological changes in the peri-implant bone tissues under the influence of low-intensity pulsed ultrasound in the experiment over time.

\section{MATERIALS AND METHODS.}

Experimental studies were carried out on 77 Chinchilla rabbits divided into three groups: 1 st - the comparison group (27 rabbits), 2nd and 3rd - the experimental groups - also 25 rabbits each. All implants were inserted into the tibial bone under general and local anaesthesia.

In the 1st group (control) the laboratory animals had the implants installed in tibiae using «traditional» method recommended by the manufacturer (without the use of low-intensity pulsed ultrasound). In the 2nd (experimental) group dental implants were subjected to low-intensity low-frequency pulsed ultrasound during the process of insertion (10-15 seconds). The 3rd group of laboratory animals had ultrasound applied to dental implants during their insertion plus subsequent contact exposure of peri-implant area with low-intensity low-frequency pulsed ultrasound (for 7 days 10 minutes a day). The histological and histomorphometric assessment was performed at 1st, 2nd, 4th, and 8th week after implantation.

Rabbit tibiae bone blocks containing dental implants were fixed in 10\% neutral formalin for 48 hours. Decalcification was performed using EDTA with obligatory control of the process completeness with calcium oxalate. The implants were removed from the bone after decalcification. Then washed in running water for 24 hours, dehydrated in alcohols of increasing concentration (70, 80, 96, absolute alcohol). The material carried through the alcohol-chloroform, chloroform, chloroform-paraffin and embedded in paraffin. From the paraffin blocks were sectioned 5.4 microns thick, which were stained with hematoxylin and eosin. Study of micropreparations was performed using DMLS microscope and software («Leica», Germany).

\section{- RESULTS AND DISCUSSION.}

In 1 week after implantation in the first group of animals at the perimeter of the implant cavity areas of lamellar maternal bone, necrotic structureless masses and zones of bone matrix resorption could be defined (Fig. 1).

Small areas of granulation and fibroreticular tissue were identified. Inter-trabecular spaces were filled with yellow bone marrow and small areas of red bone marrow with foci of necrosis. Necrotic death of single-parent bone osteocytes, inflammatory infiltration in the periosteum and low blood vessels density were observed.

In the second group of animals, the gap between the implant and regenerate was filled with connective tissue. Granulation tissue was more mature than in the control group and was dominated by a fibrous component and blood capillaries (Fig. 2).

In the maternal bone resorption areas were filled with fibroreticular tissue with a high density of osteogenic cells. Osteoblasts were single-row, compact, maternal bone matrix had normal structure, osteocytes lie freely in bone lacunae, the number and shape of the Haversian canals were not changed.

In the third group of animals a connective tissue capsule formation, comprising of areas of fibroreticular and granulation tissue, was observed throughout the implant cavity perimeter. Granulation tissue was replaced by fibroreticular at considerable length of the perimeter of the implant cavity (Fig. 3).

Granulation tissue was characterized by the presence of different diameter blood capillaries containing endothelial layer. Trabecular cavities 
were filled with bone marrow with a high density of cells of fibroblastic type. There were no necrotic areas.

In 2 weeks after implantation in the first group of animals, peri-implant space was mostly occupied by a newly formed bone tissue. Also, small areas of granulation and dense fibrous tissue were determined (Fig. 4).

Bone trabeculae were oriented at different angles and parallel to the surface of the implant. Inter-trabecular spaces were filled with fibroreticular tissue with high osteoblastic density on the trabeculae surface. Not in all areas of newly formed bone osteogenic cells were observed, and coarse fibrous tissue dominated.

In the second group 2 weeks after implantation connective tissue capsule around implants formed mostly fibroreticular newly formed bone and small areas of mature granulation tissue. The newly formed bone trabeculae were oriented for the most part parallel to the surface of the implant (Fig. 5).

On the trabeculae surface, single osteocytes and compactly situated osteoblasts were determined. In the inter-trabecular space areas of fibroreticular tissue and red bone marrow with blood vessels was visualized.

In the third animal group, the perimeter of the implant cavity is determined by newly formed bone tissue consisting of osteoid trabeculae forming marrow spaces (Fig. 6).

Inter-trabecular spaces are filled with fibroreticular tissue and red bone marrow. Well distinguished are active osteoblasts on the trabeculae surface and osteocytes in the bone matrix. This marks the beginning of lamellar bone formation.

In 1 month after implantation, the results of the first group were characterized by the presence of peri-implant fibroreticular tissue, woven bone tissue, but with remaining small foci of granulation tissue, quite immature, multicellular and with low vascularity (Fig. 7).

Inter-trabecular spaces were filled with fibroreticular tissue, areas of maternal trabeculae bone resorption and osteoclasts were visualized.

In the second group of rabbits at 1 month, a significant thickening of the periosteum on the border with the implant is observed. Also, increasing proliferation of inner osteogenic layer of the periosteum and the formation of trabecular bone can be seen (Fig. 8).

In the newly formed bone, the abundance of osteocytes in bone matrix and osteoblasts compactly arranged on the surface of bone trabeculae is observed.

The third group of animals at 1 month was determined by newly formed predominately lamellar bone tissue throughout the implant cavity. (Fig. 9).

Bone trabeculae oriented mainly parallel to the surface of the implant. Clear border connections are not traced to the parent bone. The Haversian cavities are filled with red bone marrow with functioning blood vessels.

After 2 months, in the second and third groups of animals, compact bone with woven trabeculae and lamellar bone areas was observed. Newly formed osteons and areas of mature lamellar bone were identified. In peri-implant region, vascular network with erythrocytes in the lumen of the newly formed blood vessels could be seen. Areas of fibroreticular tissue were not present. In the first animal group, peri-implant bone area was visually less than in the second and third groups (Fig. 10).

Woven bone areas with low density of osteogenic cells and areas of fibroreticular tissue filling inter-trabecular spaces were observed. In the second group areas of lamellar bones prevailed over the newly formed woven bone (Fig. 11).

In the inter-trabecular spaces, red bone marrow with numerous blood capillaries is visualized. The newly formed osteons and the border with matrix bone can be seen. The animals of the third group, for the most part, had formed lamellar bone of normal histological structure around the perimeter of the implant cavity (Fig. 12).

There is a large number of osteocytes on the bone surface and red bone marrow in the intertrabecular spaces. There is no border observed between newly-formed and matrix bone.

\section{- CONCLUSION}

The processes of osseointegration of dental implants in all groups of animals occurred without disrupting the normal process sequence. In the early stages granulation tissue is formed, later it is replaced by fibrous-reticular and coarse-fibrous bone tissue, and at the end - by a more mature lamellar bone tissue. However, the timing and degree of maturation of bone tissue, as well as osseointegration of implants in groups using low-frequency low-intensity pulsed ultrasound and without it differed significantly.

Thus, in the first group of rabbits, maturation of bone tissue is observed, consisting of necrosis zones, immature granulation tissue, defects of the maternal bone in the early period and the predominance of coarse fiber tissue in later terms of osteosynthesis, there is no complete integration of bone regenerate with the implant. The ultrasonic effect on the implants in the second group of animals contributes to a more complete integration of the 


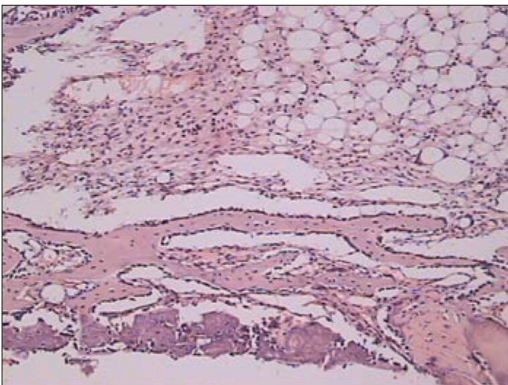

Fig. 1. The morphological features of periimplant tissues in experimental animals of the first group at 1 week (H \& E stain, x200).

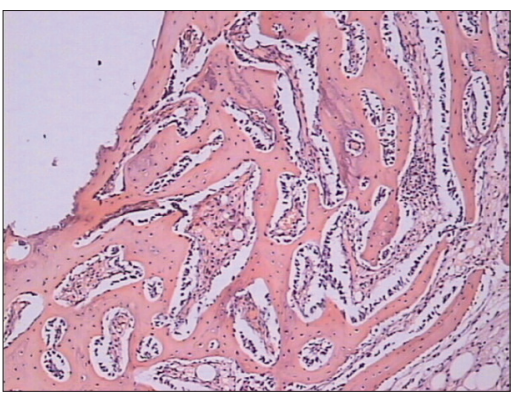

Fig. 4. The morphological features of periimplant tissues in experimental animals of the first group at 2 weeks (H \& E stain, x200).

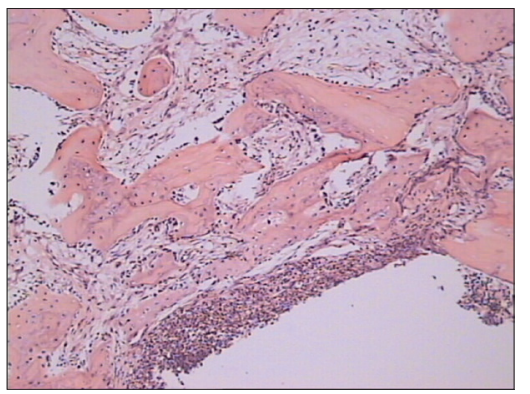

Fig. 7. The morphological features of periimplant tissues in experimental animals of the first group at 1 month (H \& E stain, x200).

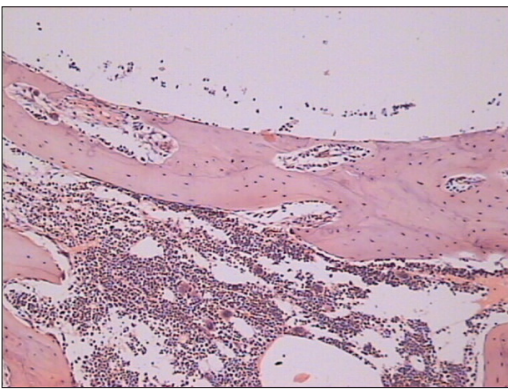

Fig. 10. Morphological signs of peri-implant tissues in experimental animals the first group after 2 months (H \& E stain, x200)

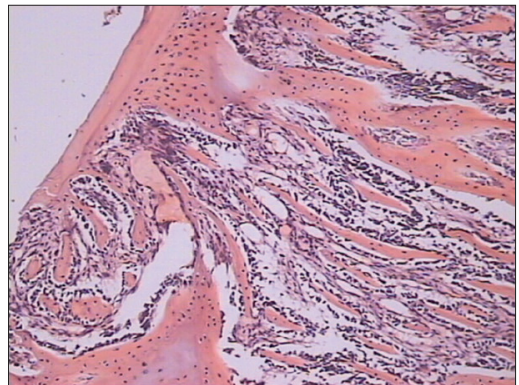

Fig. 2. The morphological features of periimplant tissues in experimental animals of the second group at 1 week (H \& E stain, x200).

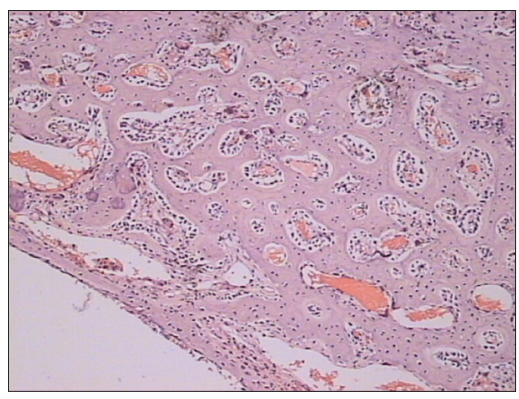

Fig. 5. The morphological features of periimplant tissues in experimental animals of the second group at 2 weeks (H \& E stain, x200).

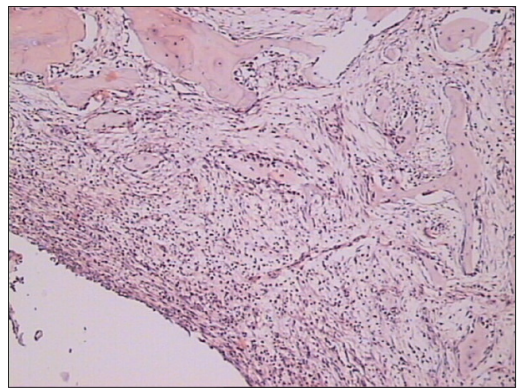

Fig. 8. The morphological features of periimplant tissues in experimental animals of the second group at 1 month (H \& E stain, x200).

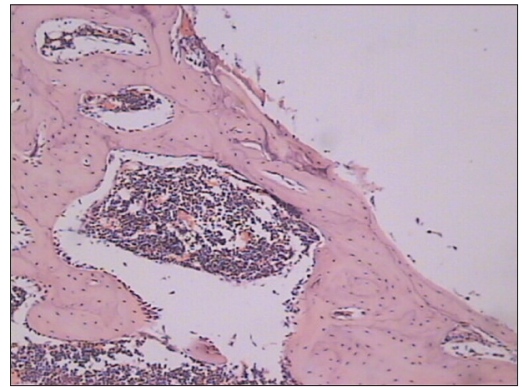

Fig. 11. Morphological signs of peri-implant tissues in experimental animals of the second group at 2 months (H \& E stain, $x 200$ ).

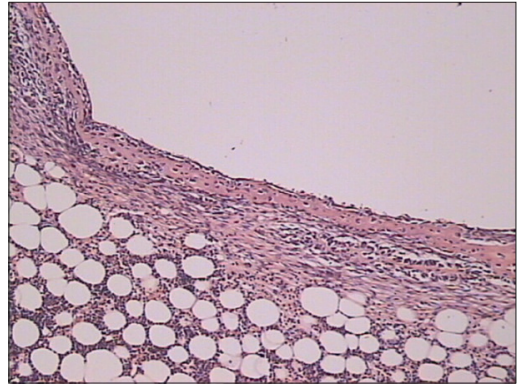

Fig. 3. The morphological features of periimplant tissues in experimental animals of the third group at 1 week (H \& E stain, x200).

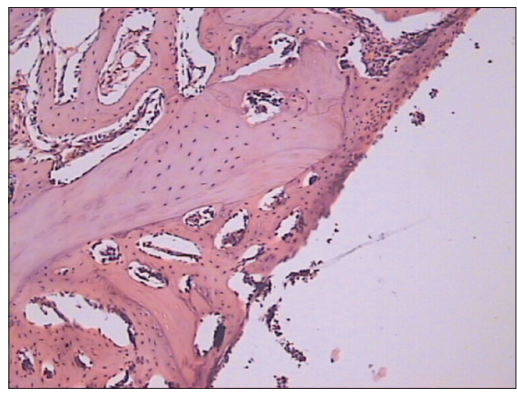

Fig. 6. The morphological features of periimplant tissues in experimental animals of the third group after 2 weeks (H \& E stain, x200).

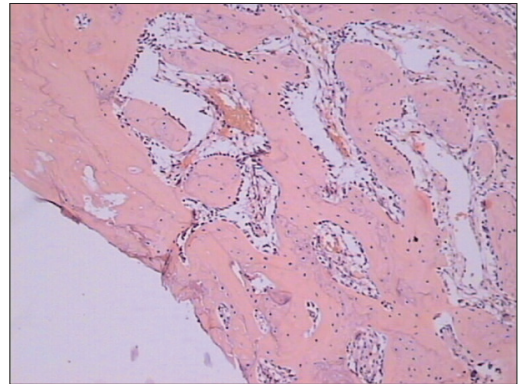

Fig. 9. The morphological features of periimplant tissues in experimental animals of the third group after 1 month (H \& E stain, x200).

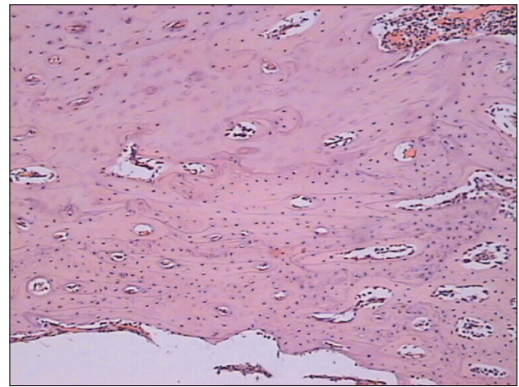

Fig. 12. Morphological signs of peri-implant tissues in experimental animals of the third group at 2 months (H \& E stain, x200). 
newly formed bone tissue with the implant surface than in the first group of animals. Dental implantation with ultrasound application to implants and subsequent ultrasonic application to peri-implant tissues in the third group induces osteoreparation processes, stimulating neoangiogenesis in granulation and newly formed bone tissue, contributes to the formation of bone tissue identical by histostructure to the maternal bone.

\section{References}

1. Khomich I.S., Rubnikovich S.P., Khomich S.F. Dentalnaya implantaciya i protezirovanie u pacienta s saharnym diabetom [Dental implantation and prosthetics in patient with diabetes]. Stomatolog. Minsk. - Stomatologist, Minsk. 2014, no. 3 (14), pp. 67-69.

2. Rubnikovich S.P. Lechenie pacientov s polnoj adentiej verhnej chelyusti sjemnymi protezami s oporoj na dentalnye implantaty [Treatment of patients with fully edentulous maxilla using implant supported dentures]. Stomatolog. Minsk. - Stomatologist, Minsk. 2015, no. 3 (18), pp. 29-36.

3. Rubnikovich S.P., Khomich I.S. Kostnye transplantaty i ih zameniteli dlya ustraneniya defektov i augmentacii chelyustnyx kostey v implantologii i periodontologii [Bone transplants and their substitutes for defect elimination in implantology and periodontology]. Stomatolog. Minsk. - Stomatologist, Minsk. 2014, no. 1 (12), pp. 77-86.

4. Albrektsson T. Osseointegrated titanium implants. Requirements for ensuring a long-lasting, direct bone-to-implant anchorage in man. Acta Orthop. Scand., 1981, vol. 52, no. 2, pp. 155-170.

5. Albrektsson T., Sennerby L., Wennerberg A. State of the art of oral implants. Periodontol. 2000. - 2008, vol. 47, pp. 15-26.

6. Azuma Y. [et al.] Low-intensity pulsed ultrasound accelerates rat femoral fracture healing by acting on the various cellular reactions in the fracture callus. J. of Bone and Miner. Res., 2001, vol. 16, no. 4, pp. 671-680.

7. Barros R.R. [et al.] Effect of biofunctionalized implant surface on osseointegration: a histomorphometric study in dogs. Braz. Dent. J., 2009, vol. 20, no. 2, pp. 91-98.

8. Decker J.F. [et al.] Evaluation of implants coated with recombinant human bone morphogenetic protein-2 and vacuum-dried using the criticalsize supraalveolar peri-implant defect model in dogs. The J. of Periodontol, 2010, vol. 81, no. 12, pp. 1839-1849.

9. Dyson M., Suckling J. Stimulation of tissue repair by ultrasound: a survey of the mechanisms involved. Physiotherapy, 1978, vol. 64, no. 4, pp. $105-108$.

10. Erdogan O., Esen E., Ustün Y., Kürkçü M., Akova T., Gönlüşen G., Uysal H., [et al.] Effects of low-intensity pulsed ultrasound on healing of mandibular fractures: an experimental study in rabbits. Journal of Oral and Maxillofacial Surgery, 2006, vol. 64 (2), pp. 180-188.

11. Hardjiargyrou M. [et al.] Enhancement of fracture healing by low intensity ultrasound. Clin. Orthop. and Relat. Res., 1998, no. 355, pp. 16-29.

12. Hasuike A. [et al.] In vivo bone regenerative effect of low-intensity pulsed ultrasound in rat calvarial defects. Oral Surg., Oral Med., Oral

Pathol., Oral Radiol. and Endod., 2011, vol. 111, no. 1, pp. e12-e20.

13. Khan Y., Laurencin C.T. Fracture repair with ultrasound: clinical and cell-based evaluation. The J. of Bone and Joint Surg. Am., 2008, vol. 90, suppl. 1, pp. 138-144.

14. Leung K.S. [et al.] Low intensity pulsed ultrasound stimulates osteogenic activity of human periosteal cells. Clin. Orthop. and Relat. Res., 2004, no. 418, pp. 253-259.

15. Lutz R. [et al.] Biofunctionalization of titanium implants with a biomimetic active peptide (P-15) promotes early osseointegration. Clin. Oral Implants Res., 2010, vol. 21, no. 7, pp. 726-734.

16. Man J., Shelton R.M., Cooper P.R., Scheven B.A. Low-intensity low-frequency ultrasound promotes proliferation and differentiation of odontoblast-like cells. Journal of Endodontics, 2012, vol. 38(5), pp. 608-613.

17. Mendonca G. [et al.] Advancing dental implant surface technology from micron- to nanotopography. Biomaterials, 2008, vol. 29, no. 28, pp. 3822-3835.

18. Naruse K. [et al.] Prolonged endochondral bone healing in senescence is shortened by low-intensity pulsed ultrasound in a manner dependent on COX-2. Ultrasound in Med. \& Biol, 2019, vol. 36, no. 7, pp. 1098-1108.

19. Novicoff W.N. [et al.] Critical analysis of the evidence for current technologies in bone-healing and repair. The J. of Bone and Joint Surg. Am., 2008, vol. 90, suppl. 1, pp. 85-91.

20. Pounder N.M., Harrison A.J. Low intensity pulsed ultrasound for fracture healing: A review of the clinical evidence and the associated biological mechanism of action. Ultrasonics., 2008, vol. 48, no. 4, pp. 330-338.

21. Rawool N.M. [et al.] Power doppler assessment of vascular changes during fracture treatment with low-intensity ultrasound. J. of Ultrasound in Med., 2003, vol. 22, no. 2, pp. 145-153.

22. Rutten S. [et al.] Low-intensity pulsed ultrasound increases bone volume, osteoid thickness and mineral apposition rate in the area of fracture healing in patients with a delayed union of the osteotomized fibula. Bone, 2008, vol. 43, no. 2, pp. 348-354.

23. Scheven B.A, Man, J., Millard J.L., Cooper P.R., Lea S.C., Walmsley A.D., Smith A.J. VEGF and odontoblast-like cells: stimulation by low frequency ultrasound. Archives of Oral Biology, 2009, vol. 54 (2), pp. 185-91.

24. Schortinghuis J. [et al.] Ultrasound to stimulate mandibular bone defect healing: a placebo-controlled single-blind study in rats. J. of Oral and Maxillofac. Surg., 2004, vol. 62, no. 2, pp. 194-201.

25. Tobita K. [et al.] Effect of low-intensity pulsed ultrasound stimulation on callus remodelling in a gap-healing model: Evaluation by bone morphometry using three-dimensional quantitative micro-CT. J. of Bone and Joint Surg., 2011, vol. 93, no. 4, pp. 525-530.

26. Ueno T. [et al.] Effect of ultraviolet photoactivation of titanium on osseointegration in a rat model. The Int. J. of Oral \& Maxillofac. Implants, 2010, vol. 25, no. 2, pp. 287-294

The authors presented the statement with the supplement of documents for the open publications / Авторами предоставлено заявление с приложением документов для открытой печати.

$$
\begin{gathered}
\text { «ВЫСТАВКА-ФОРУМ } \\
\text { "АЕНТАА-ЭКСПО. САМАРА"» } \\
\text { Аата провеАения: } 7 \text { - } 9 \text { ноября } 2018 \\
\text { Место провеАения: Россия, Самара, ВЦ «Экспо-Волга», } \\
\text { ул. Мичурина, 23А } \\
\text { Контактные Аанные: +7 (846) 207-11-39 }
\end{gathered}
$$

